\title{
Risk Implications of Increased Off-Balance Sheet Disclosure: The Case of FIN 46 and SOX
}

\author{
Carolyn M. Callahan (Corresponding Author) \\ University of Memphis, 200 A Fogelman College Administration Building \\ Memphis, TN, 38152, United States \\ Tel: 1-901-678-4569Ｅ-mail: cmcllhan@memphis.edu
}

Angela Wheeler Spencer

Oklahoma State University, 428 Business Building

Stillwater, OK, 74078, United States

Tel: 1-405-744-2863 E-mail: angela.spencer@okstate.edu

Received: September 8, 2012

Accepted: October 9, $2012 \quad$ Online Published: October 15, 2012

doi:10.5430/afr.v1n2p126

URL: http://dx.doi.org/10.5430/afr.v1n2p126

\begin{abstract}
This study investigates the impact of increased disclosures required by Financial Accounting Standards Board (FASB) Financial Interpretation No. 46 (FIN 46) Consolidation of Variable Interest Entities and the Sarbanes-Oxley Act of 2002 (SOX). Our results indicate that the maximum risk disclosures required under FIN 46 were only marginally priced, although differences exist across type of VIE and whether the structure was ultimately consolidated. Further, while all firms experienced decreases in idiosyncratic risk around this time of increasing regulatory scrutiny and upon adoption of SOX, only the off-balance sheet disclosures required by FIN 46 appear to have significantly altered firm idiosyncratic risk beyond the general provisions of SOX. Our study has implications for accounting regulators determined to design effective investor protection regulation.
\end{abstract}

Keywords: Off-balance sheet, FIN 46, Sarbanes-Oxley, VIE, SPE

\section{Introduction}

In this study we investigate the impact of increased disclosures required by Financial Interpretation No. 46 (FIN 46) (Note 1), Consolidation of Variable Interest Entities and the Sarbanes-Oxley Act of 2002 (SOX). FIN 46 requires disclosure of the maximum amount of risk associated with unconsolidated (off-balance sheet) variable interest entities (VIEs) and SOX requires discussion of off-balance sheet structures within the Management Discussion and Analysis (MD\&A). Considering the cost of preparing and certifying these disclosures is high and debate about the volume of financial statement disclosure continues, the impact of these regulations should be investigated. Further, as the FASB has recently amended accounting standards for off-balance sheet structures, (Note 2) study of this issue is particularly timely. To investigate the issue, we examine value relevance of the quantitative maximum risk disclosures made under FIN 46 and idiosyncratic risk change around both standards.

Largely in response to the series of accounting scandals that began in 2001 (in particular, the downfall of Enron), the FASB instituted FIN 46 in 2003 to correct perceived deficiencies in accounting for off-balance sheet structures. Rather than look to controlling equity interest as the primary factor to trigger consolidation, the standard instead requires consolidation of structures by that entity with the most potential loss or reward associated with the VIE. Even when structures were not consolidated, however, the standard also requires additional disclosures, including the firm's maximum amount at risk. We investigate the impact of this latter provision.

In the same era, and for many of the same reasons, the U.S. Congress enacted sweeping reform through the Sarbanes-Oxley Act of 2002.Although the provisions which establish the PCAOB and mandate more stringent standards for internal controls are most well-known, SOX also requires MD\&A disclosure of off-balance sheet structures. As implemented in 17 CFR Parts 228, 229 and 249, these disclosure requirements are broader reaching 
than those of FIN 46 and include off-balance sheet structures explicitly excluded from the FASB standard. We exploit this fact to examine the differential impact of the two pieces of regulation.

Ample prior evidence indicates that information that is disclosed in the notes, rather than recognized on the face of the financial statements, is priced by the market (e.g. Imhoff, Lipe, and Wright, 1993; Ely, 1995; Bauman, 2003). Other evidence indicates that disclosed amounts augmenting financial statement reporting impact market participant assessment of risk (e.g. Barth, Beaver, and Landsman, 1996; Graham, Lefanowica, and Petroni, 2003). Similar findings also exist relating to detailed descriptions about potential losses (Koonce, McAnnally, and Mercer, 2005). Considering these prior results, we first examine whether the market prices the quantitative risk disclosures required under FIN 46. If the market does not price these disclosures, it is possible that the information is either deemed irrelevant or adjustments for these amounts have been made elsewhere.

Regardless of whether or not the specific amounts are priced, we also examine whether or not a risk shift is experienced after adoption of the standards. Because use of off-balance sheet structures has been shown to be associated with internal control weakness (Doyle, Weili, and McVay, 2007), SOX may be particularly important for firms employing off-balance sheet vehicles. We therefore also examine the overall impact of this regulation on firm risk and further evaluate whether disclosures required under this standard had an incremental effect beyond that of FIN 46. The impact of these regulatory changes on firm equity risk are important because, as Gabriel and Ugochukwu (2012) note, "The existence of excessive volatility in the stock market undermines the usefulness of stock prices as a signal about the true intrinsic value of a firm (3)".

Our results indicate that the maximum risk disclosures required under FIN 46 were only marginally priced, although differences exist across type of VIE and whether the structure was ultimately consolidated. Further, while all firms experienced decreases in idiosyncratic risk around this time of increasing regulatory scrutiny and upon adoption of SOX, only the off-balance sheet disclosures required by FIN 46 appear to have significantly altered firm idiosyncratic risk beyond the general provisions of SOX.

The paper proceeds as follows: Section 2, Institutional Background; Section 3, Sample Selection; Section 4, Prior Literature and Hypotheses Development; Section 5, Models; Section 6, Empirical Analysis and Results; Section 7, Conclusions.

\section{Institutional Background}

\subsection{Financial Interpretation Number (FIN) 46}

Issued in January 2003 and subsequently revised in December 2003 (FIN 46R), Financial Interpretation Number (FIN) 46 (Note 3) alters the methodology to determine whether or not variable interest entities (VIEs) (Note 4) should be consolidated under U.S. GAAP. Previously, under Accounting Research Bulletin (ARB) 51, Consolidated Financial Statements, the primary test for consolidation was control, as evidenced by a majority ownership stake in the entity. Although ARB 51 did provide for consolidation if control was exercised in ways other than equity ownership, the most often applied test was that of voting control through equity ownership. Usually thinly capitalized, VIEs were rarely capitalized under ARB 51.

With a stated purpose to "achieve more consistent application of consolidation policies to variable interest entities ... [and] more complete information about the resources, obligations, risks, and opportunities of the consolidated enterprise"(FASB 2003, 7) and to "help financial statement users assess the enterprise's risks" (FASB 2003, 7), FIN 46 determines consolidation based upon the variable interests held. As defined by FIN 46, variable interests are "contractual, ownership, or other pecuniary interest in an entity that change with changes in the fair value of the entity's net assets exclusive of variable interests ( $\mid 2$ )." If an entity has a variable interest in a variable interest entity, it must consider the question of consolidation based on whether or not it is the primary beneficiary. Per FIN 46, the primary beneficiary is that entity responsible for absorbing the majority of the entity's expected losses or that will receive the majority of the potential reward. If an entity has a variable interest in a VIE but is not the primary beneficiary, additional disclosures are required. Specifically, FIN 46 specifies that "An enterprise that holds a significant variable interest in a variable interest entity but is not the primary beneficiary shall disclose: (a.) The nature of its involvement with the variable interest entity and when that involvement began, (b.) The nature, purpose, size, and activities of the variable interest entity, and (c.) The enterprise's maximum exposure to loss as a result of its involvement with the variable interest entity. ( $\mid 24)$.” This study focuses on firms making such disclosure.

Excluded from the provisions of FIN 46 (but impacted by provisions of Sarbanes-Oxley discussed below) are certain classes of VIEs, including qualified special purpose entities (QSPEs) (Note 5). We exploit this fact in our tests of the difference risk implications for each piece of regulation. 


\subsection{Sarbanes-Oxley Act of 2002}

Signed into law on July 30, 2002, the Sarbanes-Oxley Act of 2002 (SOX) mandated sweeping reform, including provisions designed to "enhance corporate responsibility, enhance financial disclosures and combat corporate and accounting fraud (SEC)." The act also established the Public Company Accounting Oversight Board (PCAOB). While the internal control and audit-related provisions of SOX have received substantial attention in the academic literature, we focus on the additional financial disclosures required by the act. In particular, we consider the disclosures required regarding off-balance sheet structures.

As implemented by SEC amendment "Disclosure in Management's Discussion and Analysis about Off-Balance Sheet Arrangements and Aggregate Contractual Obligations" (17 CFR Parts 228, 229, and 249), SOX requires that firms provide an explanation of off-balance sheet activities within a separately captioned portion of the MD\&A. These provisions mandated by SOX were effective for fiscal years ending on or after June 15, 2003.

Part IIIA of the rule defines off-balance sheet arrangement as,

any contractual arrangement to which an unconsolidated entity is a party, under which the registrant has: an obligation under certain guarantee contracts; a retained or contingent interest in assets transferred to an unconsolidated entity or similar arrangement that serves as credit, liquidity or market risk support to that entity for such assets; any obligation under certain derivative instruments; any obligation under a material variable interest held by the registrant in an unconsolidated entity that provides financing, liquidity, market risk or credit risk support to the registrant, or engages in leasing, hedging or research and development services with the registrant.

Thus, while the disclosure provisions apply to those structures under the purview of FIN 46, they also apply to many of those excluded. Of particular interest in our study are qualified special purpose entities (QSPEs).

Required by the rule are disclosures about the material facts and circumstances of the off-balance sheet structures that "provide investors with a clear understanding of a registrant's off-balance sheet arrangements and their material effects." Enumerated information is explicitly required "only to the extent necessary to an understanding of the registrant's off-balance sheet arrangements". Therefore, while quantitative details may be provided, they are not necessarily required. Further, in the course of gathering this sample, we observed that for firms making disclosure under FIN 46, the MD\&A discussion added little if any new information.

\section{Sample Selection}

For the value relevance portion of our study, we first searched for maximum risk disclosures in the period of FIN 46 adoption (filings made in 2004 for the 2003 fiscal year end). Using 10-K Wizard, we searched annual reports filed with the Securities and Exchange Commission (SEC) in 2004 for occurrences of key words related to FIN 46 such as "FIN 46" and "variable interest entity/entities". We then evaluated the disclosure related to FIN 46 adoption, noting those firms that indicate an exposure to risk in the context of the standard. This process yields 64 firms with complete data to perform our analysis. 49 of these firms do not consolidate any VIE; 15 consolidate a VIE which is either directly or indirectly linked to the maximum risk disclosure made. FIN 46 did not require that firms consolidating VIEs (primary beneficiary firms) make disclosures about the maximum risk associated with such structures. We further classify the firms based on the purpose of the VIE, creating two categories: "finance" for structures facilitating leases, securitization of loans (that are not QSPEs), etc. (24 firms) and "operating" for structures facilitating arrangements with affiliates, joint ventures, etc. (40 firms). While the majority of these firms are headquartered in the United States (63), one is headquartered in the Cayman Islands. In the course of reviewing these FIN 46 disclosures, we also identified 69 firms that have a single VIE which is consolidated (and for which we have adequate available data) which we use as a benchmark in our risk analysis. We denote this sample as the "CON" subset.

For the risk analysis portion of our study, we employed the direct EDGAR proximity search feature to examine filings made with the SEC in order to identify firms making explicit disclosures about off-balance sheet structures following adoption of FIN 46 and SOX (filings made in 2004 and 2005 for the 2003 and 2004 fiscal year ends). First, to identify the FIN 46 sample, we searched for the phrase "maximum exposure" in close proximity to the term VIE. We used the phrase "maximum exposure" considering the explicit requirement in FIN 46 that "maximum exposure to loss" in unconsolidated VIEs be disclosed. From this procedure, we identified 53 firms with specific, quantitative disclosures as described above and adequate data. We denote these as the "VIE" sample. Similarly, we searched for the phrase "off balance sheet" in close proximity to "QSPE" within the MD\&A to detect those firms making disclosures under SOX for vehicles not under the provisions of FIN 46. SOX, as implemented with 17 CFR Parts 228, 
229 and 249 requires that off-balance sheet structures be discussed in the MD\&A. 34 QSPE firms (not already included in our VIE sample) with sufficient data were identified. We label these firms as the "QSPE" sample.

These samples allow us to contrast the implications of off-balance sheet structures subject to consolidation (VIEs) against those not subject to recognition (QSPEs). They also enable us to contrast the effect of each disclosure against the overall effect from adoption of SOX (and increased regulatory requirements, generally) by comparing the off-balance sheet firms (VIE and QSPE firms) against those firms with formerly off-balance sheet structures now consolidated (CON firms). While the vast majority of the sample employed in the risk analysis is composed of firms based in the United States, five are headquartered in other locations: one in Canada, one in Switzerland, one in the Cayman Islands, one in Puerto Rico, and one in Singapore.

\section{Prior Literature and Hypotheses Development}

Prior literature provides ample evidence that disclosures should be important to market participants. For example, one group (Imhoff et al, 1993; Ely, 1995; Beattie, Goodacre, and Thomson, 2000) examines operating lease disclosures and finds them to be of significant importance in the assessment of equity risk. Bauman (2003) likewise shows that obligations accounted for under the equity method of accounting (and thus, essentially off-book) are priced. From this evidence, we can therefore expect that, even if structures remain off-balance sheet, they are important to market participants in evaluating firms.

Further, other work shows that disclosures supplementing recognized items are also considered. For instance, Barth, et al. (1996) shows this effect for fair value disclosures regarding loan losses as does Graham et al. (2003) for fair value disclosures related to equity method investments. Further, Koonce, McAnnally, and Mercer. (2005) show that disclosures about potential loss incomes have significant influence over financial statement users.

Although, by themselves, the disclosure provisions of FIN 46 and SOX do not change the expected future cash flows of the firm, assuming investors understand the disclosures, they may in fact change the risk assessment assigned. In other words, by revealing a more transparent picture of potential firm obligations, financial statement users may be able to make more accurate judgments about firms with arrangements structured through variable interest entities. Because FIN 46 requires quantification of this additional risk, we examine the value relevance of those disclosures, proposing:

\section{H1: Maximum risk disclosures made under FIN 46 are value relevant.}

Because these disclosures explicitly reveal risk that may have been previously hidden (or at least somewhat obscured), firms with off-balance sheet structures impacted by the standard may experience an increase in market assessed risk. Even if this risk was well understood prior to adoption of FIN 46, it is also possible that adoption of this standard may have negative contracting implications for affected firms. For instance, Callahan, Smith, and Spencer (2012a) document an increase in cost of capital for firms adopting FIN 46 and Zhang (2007) finds substantial negative economic consequences associated with adoption of SOX. Conversely, a substantial amount of work (e.g. Botosan, 1997; Botosan and Plumlee, 2002 among others) shows that increased disclosure has a positive (decreasing) impact on firm cost of capital. Further, Callahan, Smith, and Smith (2012b) document an increase in reliability associated with adoption of FIN 46and Chang, Fernando, and Liao. (2009) find that SOX is associated with positive effects on cost of capital. Given that our sample firms should benefit from the positive effects associated with SOX and corresponding increased disclosure of both standards, ex ante, it is unclear whether these forces will dominate any negative consequences of increased information about off-balance sheet risk. Thus, we propose:

\section{H2: Disclosure under FIN 46 is risk relevant for firms with off-balance sheet structures.}

\section{H3: Disclosure under SOX is risk relevant for firms with off-balance sheet structures.}

Assuming that the disclosures relating to off-balance financing as required by FIN 46 (within the notes to the financial statements) and the disclosures required by SOX (in the MD\&A) are both risk relevant, at question next is whether they provide different levels of risk relevance. Even in light of the evidence cited above, it is difficult to assess whether disclosures under these standards work jointly to increase or decrease risk assessment or whether they have competing effects. First, given the post-Enron environment, additional information about these entities may be far less important than the quality of the firm's information product as a whole. Especially considering that Doyle, et al. (2007) find that off-balance sheet special purpose entities are associated with weak internal controls, improved information required under these standards may be very important in market evaluation of firms with off-balance sheet structures. That is, while the increased information provided with disclosures under both standards may alter risk, application of the provisions of SOX (and the intervening improved governance) may also have a significant 
impact by decreasing information risk. However, as our evidence cited in support of the preceding hypotheses suggests, revelation of these associated risks may likewise increase market assessed risk. Because it is unclear which effect should dominate, we have no clear expectations about the directions of these effects and instead propose:

H4: Disclosure under FIN 46 and disclosure under SOX provide differential risk relevance for firms with off-balance sheet structures.

\section{Models}

\subsection{Value relevance of FIN 46 maximum risk disclosures (H1)}

To examine H1, assessing the value relevance of maximum risk disclosures under FIN 46, we analyze the following models:

$$
M V E_{i t}=\beta_{0}+\beta_{1} B V A_{i t}+\beta_{2} B V L_{i t}+\beta_{3} M A X_{-} R I S K_{i t}+\varepsilon_{i t}
$$

Where:

$M V E=$ Per share price at the end of the first quarter following the end of the fiscal year.

$B V A=$ Book value of assets scaled by total shares outstanding.

$B V L=$ Book value of liabilities scaled by total shares outstanding.

$M A X \_R I S K=$ Maximum VIE risk disclosed by the firm scaled by total shares outstanding.

However, because existing work shows differences across various types of alliances and joint ventures (e.g. Kohand Venkatraman, 1991; Chan, Kensigner, Keown, and Martin, 1997; and Das, Sen, and Sengupta, 1998) and because Feng, Gramlich, and Gupta (2009) find that financial-type SPVs have a stronger association with earnings management than do SPVs with economic motivation, we further examine:

$$
M V E_{i t}=\beta_{0}+\beta_{1} B V A_{i t}+\beta_{2} B V L_{i t}+\beta_{3} M A X \_R I S K_{i t} * F I N A N C E_{i t}+\beta 4 M A X \_R I S K_{i t} * O P E R A T I N G_{i t}+\varepsilon_{i t}
$$

Where:

FINANCE $=1$ if the VIE is structured to facilitate a financing or lease transaction and 0 otherwise.

OPERATING $=1$ if the VIE is structured to facilitate a joint venture, partnership, or investment and 0 otherwise.

Finally, while for firms consolidating a VIE, maximum risk disclosures have only a potential incremental contribution to otherwise recognized amounts, disclosures made by firms not consolidating their VIE may be far more meaningful and may be the only quantitative disclosure about the underlying total risk related to the structure. As a result, we examine:

$M V E_{i t}=\beta_{0}+\beta_{1} B V A_{i t}+\beta_{2} B V L_{i t}+\beta_{3} M A X_{-} R I S K_{i t} * O N-B O O K_{t}+\beta 4 M A X_{-} R I S K_{i t} * O F F-B O O K_{i t}+\varepsilon_{i t}$

Where:

$O N-B O O K=1$ if the maximum risk disclosure pertains to a consolidated VIE.

$O F F-B O O K=1$ if the maximum risk disclosure pertains to a VIE that is not consolidated.

\subsection{Risk relevance of FIN 46 and $\mathrm{SOX}(\mathrm{H} 2-\mathrm{H} 3)$}

To examine the risk effects of FIN 46 and SOX, we draw upon the work of Ashbaugh-Skaife, Collins, Kinney, and LaFond (2009), which examines the effect of internal control deficiencies (reported under SOX) on firm risk. We first begin with a baseline model based on this work:

$$
\begin{aligned}
I_{-} R I S K_{i t}=\beta_{0}+\beta_{1} C F O_{i t}+\beta_{2} S D \_C F O_{i t}+ & \beta_{3} L E V_{i t}+\beta_{4} B K_{-} M K T_{i t} \\
& +\beta_{5} S I Z E_{i t}+\beta_{6} P A Y E R_{i t}+\beta_{7} R E T U R N_{i t}+\varepsilon_{i t}
\end{aligned}
$$

Where:

$I \_R I S K=$ idiosyncratic risk estimated as the standard deviation of residuals from estimating $E X R E T=\beta_{0}+\beta_{1} R M R F+\varepsilon$ using monthly returns for each time period, PRE, TRAN, POST, where EXERT = firm's monthly return - risk free rate (proxied as 3-month T-bill) and $R M R F=$ excess market return from Ken French's website.

$C F O=$ cash flow from operations reported for the last fiscal year of each period (PRE, TRAN, POST).

$S D \_C F O=$ standard deviation of cash flow from operations for each period (PRE, TRAN, POST)

$L E V=$ debt-to-assets ratio for the last fiscal year of each period (PRE, TRAN, POST) 
$B K \_M K T=$ book-to-market for the last fiscal year of each period (PRE, TRAN, POST)

$S I Z E=$ natural log of market value of equity for the last fiscal year of each period (PRE, TRAN, POST)

$P A Y E R=1$ if firm paid dividends in a given period (PRE, TRAN, POST)

RETURN= buy-and-hold return for the last fiscal year of each period (PRE, TRAN, POST)

We next expand this model to examine the general effects across the time periods studied here. Following other work examining regulatory change (for instance, Dhaliwal, Chen, and Xie 2010), we divide our sample period into three components: a "pre" period before the regulatory shift; a transitory ("tran") period during the development and initial release of information under the new regulations; and a "post" period following full adoption of the new regulations. First, we define the 12 quarter period beginning with the third quarter of 1998 and ending in the second quarter of 2001 as the "pre" period. While off-balance sheet structures were in use during this period, this time predates the accounting scandals which prompted regulatory change. Because the course of the accounting scandals that prompted this change developed over several months and because both FIN 46 and SOX were in development over time, we denote the 6 quarter period beginning with the $3^{\text {rd }}$ quarter of 2001 (Enron began to unravel over the fall of 2001) through the fourth quarter of 2002 as the "tran" period. We then define the "post" period as the 12 quarter period beginning in January 2003 (the first iteration of FIN 46 was effective in January 2003) through the last quarter of 2005. We extend the "post" period for a full 12 quarters because the details and implementation practices of both standards continued to evolve over this time. The model to examine the generalized shifts in risk across these periods is:

$$
\begin{aligned}
I_{-} R I S K_{i t}=\beta_{0}+\beta_{I} C F O_{i t}+\beta_{2} S D_{-} C F O_{i t}+\beta_{3} L E V_{i t}+\beta_{4} B K_{-} M K T_{i t} \\
\\
+\beta_{5} S I Z E_{i t}+\beta_{6} P A Y E R_{i t}+\beta_{7} R E T U R N_{i t}+\beta_{8} T R A N_{i t}+\beta_{9} P O S T_{i t}+\varepsilon_{i t}
\end{aligned}
$$

Where:

$T R A N=1$ if during the transition period $\left(20013^{\text {rd }}\right.$ quarter to $20024^{\text {th }}$ quarter $)$

$P O S T=1$ if during the post FIN 46 period (2003 $1^{\text {st }}$ quarter to $20054^{\text {th }}$ quarter)

Next, because the adoption of SOX and the corresponding control improvements required by the standard should have provided firms with a general enhancement in information risk, we examine:

$$
\begin{aligned}
I_{-} R I S K_{i t}= & \beta_{0}+\beta_{I} C F O_{i t}+\beta_{2} S D_{-} C F O_{i t}+\beta_{3} L E V_{i t} \\
& +\beta_{4} B K_{-} M K T_{i t}+\beta_{5} S I Z E_{i t}+\beta_{6} P A Y E R_{i t}+\beta_{7} R E T U R N_{i t}+\beta_{8} S O X_{i t} \varepsilon_{i t}
\end{aligned}
$$

Where:

$S O X=1$ if the firm presented an assessment of internal controls (in accordance with SOX) as reported within Audit Analytics.

Because the types of off-balance sheet structures examined here (VIEs and QSPEs) may have had different risk implications outside of these regulatory requirements, we next examine:

$$
\begin{gathered}
I_{-} R I S K_{i t}=\beta_{0}+\beta_{1} C F O_{i t}+\beta_{2} S D_{-} C F O_{i t}+\beta_{3} L E V_{i t}+\beta_{4} B K_{-} M K T_{i t}+\beta_{5} S I Z E_{i t}+\beta_{6} P_{A Y E R} R_{i t} \\
+\beta_{7} R E T U R N_{i t}+\beta_{8} V I E_{i t}+\beta_{9} Q S P E_{i t}+\varepsilon_{i t}
\end{gathered}
$$

Where:

$V I E=1$ if a firm has maximum risk disclosures relating to a VIE following FIN 46 and 0 otherwise.

$Q S P E=1$ if a firm discloses involvement with a qualified special purpose entities post SOX and 0 otherwise.

Next, we examine how the risk importance of these structures changed over the regulatory developments in the time period examined here. We consider both the risk shift (by off-balance sheet structure type) as firms made initial disclosures related to the standards and as the regulation developed (TRAN period) and the risk shifts as firms fully adopted the standards (POST period):

$$
\begin{aligned}
& I_{-} R I S K_{i t}=\beta_{0}+\beta_{1} C F O_{i t}+\beta_{2} S D_{-} C F O_{i t}+\beta_{3} L E V_{i t}+\beta_{4} B K_{-} M K T_{i t}+\beta_{5} S I Z E_{i t}+\beta_{6} P A Y E R_{i t} \\
& \quad+\beta_{7} R E T U R N_{i t}+\beta_{8} T R A N^{*} V I E_{i t}+\beta_{9} T R A N^{*} Q S P E_{i t}+\beta_{8} P O S T^{*} V I E_{i t}+\beta_{9} P O S T^{*} Q S P E_{i t}+\varepsilon_{i t}
\end{aligned}
$$

Finally, we examine whether the provisions of these standards offered differential risk implications. To do so, we consider both the impact of SOX and the shifts in risk associated with these structures across the TRAN and POST periods: 


$$
\begin{aligned}
& I_{-} R I S K_{i t}=\beta_{0}+\beta_{1} C F O_{i t}+\beta_{2} S D_{-} C F O_{i t}+\beta_{3} L E V_{i t}+\beta_{4} B K_{-} M K T_{i t}+\beta_{5} S I Z E_{i t}+\beta_{6} P_{A Y Y E R_{i t}}+\beta_{7} R_{E T U R N} \\
& +\beta_{8} S O X_{i t}+\beta_{9} T R A N^{*} V I E_{i t}+\beta_{10} T R A N^{*} Q S P E_{i t}+\beta_{11} P O S T^{*} V I E_{i t}+\beta_{12} P O S T * Q S P E_{i t}+\varepsilon_{i t}
\end{aligned}
$$

\section{Empirical Analysis and Results}

Table 1 presents descriptive statistics for sample firms. With a mean $M V E$ of less than $\$ 30$ million and mean BVA of slightly more than $\$ 66$ million, sample firms are generally small. (Note 6) As Panel A further reports, the maximum risk amounts disclosed by VIE firms vary widely, with a mean of $\$ 2.072$ million and median of $\$ 0.254$ million. As Panel B shows, idiosyncratic risk $(I R I S K)$ for all firms declined across the sample period, although returns (RETURN) were negative during the transitory period. Further, by the end of the POST period, most firms had adopted the provisions of SOX $(S O X)$.

Table 2 presents correlation analysis. As presented in Panel A of Table 2, MAX_RISK is not significantly associated with any of the other variables of interest. As Panel B shows, $I_{-} R I S K$ is significantly associated with all variables except for $Q S P E$. Further, SOX appears to be associated with a decrease in $I_{-} R I S K$ with a significant correlation coefficient of -0.2330 .

Table 3 presents the results of estimating models $1 \mathrm{a}-1 \mathrm{c}$, which test H1. As presented in Table 3, coefficients on $B V A$ and $B V L$ are near their expected values of 1.0 and -1.0 , respectively. However, somewhat surprisingly, although the coefficient estimated for MAX_RISK in Model 1a is negative (-0.29), it is only marginally significant (p-value 0.11 ). When considering the differential effects of the purpose of each VIE (Model 1b), it becomes apparent that while FINANCE structures are marginally value relevant (coefficient -0.29 , p-value 0.109), OPERATING structures are not (coefficient -2.17, p-value 0.23). While this result is somewhat perplexing, it is possible that these disclosures only reiterate information provided about the structures elsewhere and thus are not incrementally informative. In other words, it is possible that only the disclosures made about FINANCE structures provide new information to the market. Finally, as Model 1c shows, while disclosures made about structures not consolidated $\left(O F F-B O O K^{*} M A X \_R I S K\right)$ approach traditional levels of significance (OFF-BOOK*MAX_RISK, coefficient -0.27 , p-value 0.13$)$, those made about structures consolidated (ON-BOOK*MAX_RISK) are not incrementally informative. Taken together, these results indicate that the maximum risk disclosures provided under FIN 46 have, at best, only marginal significance. Thus, these results provide only limited support for H1. However, beyond the quantitative disclosures, it is possible that the improvement of the total information set provided by these disclosures and new reporting regime does modify firm risk.

Turning to our idiosyncratic risk models, we next examine the results presented in Table 4. Results for the baseline model (2a) are similar to those reported by Ashbaugh-Skaife, et al. (2009), with the exception of $B K \_M K T$, which is not significant for our sample. As Model $2 \mathrm{~b}$ shows, all firms experienced significant risk decreases in both the TRAN and POST periods, with coefficients of -0.024 and -0.029 , respectively and these decreases are statistically the same. These results provide general support for $\mathrm{H} 2$ as they indicate that disclosure under the FIN 46 regime is risk relevant for firms with off-balance sheet structures. From Model 2c, we see that risk decrease is also associated specifically with the period of SOX adoption, with a decline of -0.019 . These results provide support for $\mathrm{H} 3$ as they indicate that disclosure under SOX is risk relevant for firms with off-balance sheet structures. However, from Model $2 \mathrm{~d}$, VIE and QSPE firms do not appear to have general risk differences when compared to the firms consolidating their VIEs (presented in the intercept). However, firms with either type of off-balance sheet structure do experience larger risk decreases in the POST period than do those firms that consolidate their VIEs (Model 2e), with a decrease of - 0.014 for the VIE firms and -0.012 for the QSPE firms. However, the same cannot be said for the transitory period as Model $2 \mathrm{f}$ shows, when controlling for the effect of SOX adoption, only firms with VIEs (and disclosures in the notes to the financial statements as mandated by FIN 46) experience additional risk decreases (-0.012), and those occur in the TRAN period. Taken together, these results support $\mathrm{H} 4$ as they indicate, for firms with off-balance sheet structures, differential risk effects are associated with disclosure in the notes to the financial statements made under FIN 46 and disclosure in the MD\&A made under SOX.

\section{Conclusions}

From these results, we can conclude that adoption of Sarbanes-Oxley offers incremental improvement to the firm-specific risk of entities disclosing off-balance sheet structures. However, considering the disclosure requirements of the standard, it is difficult to say that they are marginally beneficial to firms. For firms also disclosing such interests in off-balance sheet structures under FIN 46, however, additional improvements in idiosyncratic risk are observed. Unfortunately, in and of themselves, the specific quantitative disclosures required by firms under FIN 46 do not appear to offer substantial amounts of new information to the market. Given the 
"disclosure overload" that we seem to be facing, these results call into question whether all of the disclosures about off-balance sheet structures are necessary. As standard setters world -wide continue to grapple with these issue, these results should prove important.

However, it should also be noted that this study is not without limitations. First, we utilize a relatively small sample over a relatively brief window of time. As these market participants have gained familiarity with these disclosures, observed results may differ. As a result, it may prove fruitful for future research to examine whether market interpretation of these disclosures remains unchanged. Further, although we utilized a broad selection of keywords in gathering our sample, it merits noting that our method of sample selection may leave out some firms impacted by the change in standards examined here. Second, as with all empirical models, our methodology does not capture all factors which potentially impact the price or risk of a firm. As a result, expanded asset pricing and market valuation models (as they are developed) may provide greater insight into the phenomena documented here. Considering both of these points, it may prove fruitful for future research to consider alternative sample selection procedures and expanded model specifications as data becomes more readily available on regulatory disclosures and specific risk information.

\section{References}

Ashbaugh-Skaife, H., Collins, D.W., Kinney, W.R., Jr., \& LaFond, R. (2009). The effect of SOX internal control deficiencies on firm risk and cost of equity. Journal of Accounting Research, 47(1),1-43. http://dx.doi.org/10.1111/j.1475-679X.2008.00315.x

Barth, M., Beaver, W., \& Landsman, W. (1996). Value-relevance of banks' fair value disclosures under SFAS No. 107. The Accounting Review, 71(4), 513-537.

Bauman, M., (2003). The impact and valuation of off-balance-sheet activities concealed by equity method accounting. Accounting Horizons, 17(4), 303-314. http://dx.doi.org/10.2308/acch.2003.17.4.303

Beattie V., Goodacre A., and Thomson, S. (2000). Recognition versus disclosure: an investigation of the impact on equity risk using UK operating lease disclosures. Journal of Business Finance \& Accounting 27(9\&10): 1185-1224. http://dx.doi.org/10.1111/1468-5957.00352

Botosan, C. (1997). Disclosure level and the cost of equity capital. The Accounting Review, 72(3), 323-350.

and Plumlee, M. (2002). A re-examination of disclosure level and the expected cost of equity capital. Journal of Accounting Research, 40(1), 21-41. http://dx.doi.org/10.1111/1475-679X.00037

Callahan, C.M., Smith, R.E., and Spencer, A.W. (2012a). An examination of the cost of capital implications of FIN 46. The Accounting Review 87(4), 1105-1134. http://dx.doi.org/10.2308/accr-10272

Callahan, C.M., Smith, R.E., and Spencer, A.W. (2012b). The valuation and reliability implications of FIN 46 for synthetic lease liabilities. Journal of Accounting and Public Policy, forthcoming.

Chan, S.H., Kensinger, J.W., Keown,A.J.,\& Martin, J.D. (1997). Do strategic alliances create value? Journal of Financial Economics, 46, 199-221. http://dx.doi.org/10.1016/S0304-405X(97)00029-9

Chang, H., Fernando, G.D., \& Liao, W. (2009). Sarbanes-Oxley Act, perceived earnings quality and cost of capital. Review of Accounting and Finance 8(3): 216-231. http://dx.doi.org/10.1108/14757700910980831

Das, S., Sen, P.K., \& Sengupta, S. (1998). Impact of strategic alliances on firm valuation. Academy of Management Journal, 41(1), 27-41. http://dx.doi.org/10.2307/256895

Dhaliwal, D.S., Chen, Z., \& Xie, H. (2010). Regulation fair disclosure and the cost of equity capital. Review of Accounting Studies, 15, 106-144. http://dx.doi.org/10.1007/s11142-009-9115-6

Disclosure in Management's Discussion and Analysis about Off-Balance Sheet Arrangements and Aggregate Contractual Obligations. (2003).17 CFR Parts 228,229,249.

Doyle, J., Weili, G., \& McVay, S. (2007). Determinants of weakness in internal control over financial reporting. Journal of Accounting and Economics, 44, 193-223. http://dx.doi.org/10.1016/j.jacceco.2006.10.003

Ely, K. (1995). Operating lease accounting and the market's assessment of equity risk. Journal of Accounting Research, 33(2), 397-415. http://dx.doi.org/10.2307/2491495

FASB. (2003). Consolidation of variable interest entities an interpretation of ARB no. 51. Financial Interpretation Number 46 (Revised December 2003). Financial Accounting Standards Board, Norwalk, CT. 
Feng, M., Gramlich, J., \& Gupta, S. (2009). Special purpose vehicles: empirical evidence on determinants and earnings management. The Accounting Review, 84(6),1833-1876. http://dx.doi.org/10.2308/accr.2009.84.6.1833

Gabriel, A.M. \& Ugochukwu, W.M. (2012). Volatility estimation and stock price prediction in the Nigerian stock market. International Journal of Financial Research, 3(1),2-14. http://dx.doi.org/10.5430/ijfr.v3n1p2

Graham, R., Lefanowica, C., \& Petroni, K. (2003). The value relevance of equity method fair value disclosures. Journal of Business Finance and Accounting, 30(7\&8), 1065-1089. http://dx.doi.org/10.1111/1468-5957.05426

Imhoff, E., Lipe, R., \& Wright, D. (1993). The effects of recognition versus disclosure on shareholder risk and executive compensation. Journal of Accounting, Auditing, and Finance, 8(4), 335-368.

Koh, H. \& Venkatraman, N. (1991). Joint-venture formation and stock market reaction: an assessment in the information technology sector. Academy of Management Journal, 34(4), 869-92. http://dx.doi.org/10.2307/256393

Koonce, L., McAnnally, M.L., \& Mercer, M. (2005). How do investors judge the risk of financial items? The Accounting Review, 80(1), 221-241. http://dx.doi.org/10.2308/accr.2005.80.1.221

Zhang, X. (2007). Economic consequences of the Sarbanes-Oxley act of 2002. Journal of Accounting and Economics 44(1-2):74-115. http://dx.doi.org/10.1016/j.jacceco.2007.02.002

\section{Notes}

Note 1. We refer to FIN 46 and the revised FIN 46(R) collectively as "FIN 46" throughout this draft.

Note 2. SFAS No. 166 and 167, effective in 2009.

Note 3. We collectively refer to FIN 46 and FIN 46(R) as "FIN 46".

Note 4. Also known as special purpose entities (SPEs).

Note 5. Per the provisions of SFAS 140, Accounting for Transfers and Servicing of Financial Assets and Extinguishment of Liabilities. The exemption of QSPEs has subsequently been modified by SFAS 166 and 167, effective 2009.

Note 6. In contrast, the smallest Fortune 500 firm (with reported assets) in 2003, Spartan Stores, reported total assets of $\$ 746.5$ million. 
Table 1. Descriptive Statistics

Panel A:Value Relevance Variables ( $\mathrm{n}=64)$

$\begin{array}{llll}\text { Variables } & \text { Mean } & \begin{array}{l}\text { Std. } \\ \text { Dev. }\end{array} & \text { Median } \\ \text { MVE } & 29.158 & 17.693 & 25.845 \\ \text { BVA } & 66.167 & 146.389 & 29.793 \\ \text { BVL } & 52.996 & 143.223 & 16.567 \\ \text { MAX_RISK } & 2.072 & 8.995 & 0.254\end{array}$

$\underline{\text { Panel B:Risk Variables( } \mathrm{n}=156)}$

\begin{tabular}{|c|c|c|c|}
\hline Variables & Mean & $\begin{array}{l}\text { Std. } \\
\text { Dev. }\end{array}$ & Median \\
\hline \multicolumn{4}{|c|}{ PRE Period ( $2^{\text {nd }}$ quarter 1998 to $2^{\text {nd }}$ quarter 2001) } \\
\hline I RISK & 0.150 & 0.061 & 0.128 \\
\hline $\bar{C} F O$ & 0.063 & 0.077 & 0.064 \\
\hline$S D \_C F O$ & 0.040 & 0.029 & 0.039 \\
\hline$L E \bar{V}$ & 0.301 & 0.211 & 0.288 \\
\hline$B K \_M K T$ & 0.593 & 0.443 & 0.489 \\
\hline$S I \overline{Z E}$ & 7.891 & 1.950 & 7.840 \\
\hline PAYER & 0.699 & 0.460 & 1 \\
\hline RETURN & 0.193 & 0.498 & 0.138 \\
\hline$S O X$ & 0 & 0 & 0 \\
\hline \multicolumn{4}{|c|}{ TRAN Period ( $3^{\text {rd }}$ quarter 2001 to $4^{\text {th }}$ quarter } \\
\hline I_RISK & 0.129 & 0.059 & 0.105 \\
\hline $\bar{C} F O$ & 0.077 & 0.079 & 0.064 \\
\hline$S D \_C F O$ & 0.033 & 0.041 & 0.024 \\
\hline$L E \bar{V}$ & 0.294 & 0.219 & 0.275 \\
\hline$B K \_M K T$ & 0.665 & 0.412 & 0.607 \\
\hline$S I Z \bar{E}$ & 7.768 & 1.818 & 7.648 \\
\hline$P A Y E R$ & 0.673 & 0.471 & 1 \\
\hline RETURN & -0.055 & 0.401 & -0.073 \\
\hline$S O X$ & 0 & 0 & 0 \\
\hline \multicolumn{4}{|c|}{ POST Period ( $1^{\text {st }}$ quarter 2003 to $4^{\text {th }}$ quarter 2005) } \\
\hline I RISK & 0.116 & 0.031 & 0.105 \\
\hline $\bar{C} F O$ & 0.073 & 0.072 & 0.064 \\
\hline$S D \_C F O$ & 0.033 & 0.037 & 0.024 \\
\hline$L E \bar{V}$ & 0.282 & 0.216 & 0.246 \\
\hline$B K \_M K T$ & 0.500 & 0.252 & 0.477 \\
\hline$S I Z \bar{E}$ & 8.387 & 1.662 & 8.320 \\
\hline$P A Y E R$ & 0.750 & 0.434 & 1 \\
\hline RETURN & 0.101 & 0.292 & 0.045 \\
\hline$S O X$ & 0.949 & 0.221 & 1 \\
\hline
\end{tabular}

Where:

$S O X$

$M V E=$ Per share price at the end of the first quarter following the end of the fiscal year.

$B V A=$ Book value of assets scaled by total shares outstanding.

$B V L=$ Book value of liabilities scaled by total shares outstanding.

$M A X \_R I S K=$ Maximum VIE risk disclosed by the firm scaled by total shares outstanding.

I RISK $=$ idiosyncratic risk estimated as the standard deviation of residuals from estimating EXRET $=\beta_{0}+$ $\overline{\beta_{1}} R M R F+\varepsilon$ using monthly returns for five year windows, where $E X E R T=$ firm's monthly return - risk free rate (proxied as 3-month T-bill) and $R M R F=$ excess market return from Ken French's website.

$C F O=$ cash flow from operations

$S D \_C F O=$ standard deviation of cash flow from operations

$L E \bar{V}=$ debt-to-assets ratio

$B K \_M K T=$ book-to-market

$S I \overline{Z E}=$ natural $\log$ of market value of equity

$P A Y E R=1$ if firm paid dividends

$R E T=$ buy-and-hold return for the fiscal year

$S O X=1$ if the firm presented an assessment of internal controls (in accordance with SOX).

$V I E=$ firm with maximum risk disclosures relating to a VIE following FIN 46

$Q S P E=$ firm disclosing involvement with qualified special purpose entities post SOX 
Table 2. Correlation Analysis

\begin{tabular}{|c|c|c|c|c|c|c|c|c|c|c|c|}
\hline \multicolumn{12}{|c|}{ Panel A:Value Relevance Variables } \\
\hline & MVE & BVA & BVL & MAX RISK & & & & & & & \\
\hline MVE & 1.0000 & & & & & & & & & & \\
\hline BVA & $0.4079^{* * *}$ & 1.0000 & & & & & & & & & \\
\hline BVL & $0.3713^{* * *}$ & $0.9980^{* * *}$ & 1.0000 & & & & & & & & \\
\hline MAX_RISK & -0.0515 & 0.1197 & 0.1148 & 1.0000 & & & & & & & \\
\hline Panel B:Risl & $\mathrm{k}$ Variables & & & & & & & & & & \\
\hline I_RISK & $\begin{array}{l}\text { I_RISK } \\
1.0000\end{array}$ & $\mathrm{CFO}$ & $S D \_C F O$ & $L E V$ & $B K \_M K T$ & SIZE & PAYER & RETURN & SOX & VIE & $Q S P E$ \\
\hline CFO & $-0.0943 * *$ & 1.0000 & & & & & & & & & \\
\hline$S D \_C F O$ & $0.3769^{* * *}$ & -0.0469 & 1.0000 & & & & & & & & \\
\hline$L E V$ & $-0.1581^{* *}$ & $-0.1763 * * *$ & $-0.0957^{* *}$ & 1.0000 & & & & & & & \\
\hline$B K \_M K T$ & $0.1629 * * *$ & $-0.2666 * * *$ & $0.1204^{* * *}$ & 0.0350 & 1.0000 & & & & & & \\
\hline SIZE & $-0.3901^{* * * *}$ & $0.0815^{*}$ & $-0.3514 * * *$ & -0.0377 & $-0.4617 * * *$ & 1.0000 & & & & & \\
\hline PAYER & $-0.5138^{* * *}$ & -0.0635 & $-0.2749 * * *$ & $0.0937 * *$ & 0.0118 & $0.4026^{* * *}$ & 1.00000 & & & & \\
\hline RETURN & $-0.1306^{* *}$ & 0.0345 & 0.0127 & $0.0960^{* *}$ & $-0.2377^{* * *}$ & 0.0504 & 0.0641 & 1.0000 & & & \\
\hline SOX & $-0.2330^{* * *}$ & 0.0247 & -0.0659 & -0.0401 & $-0.1673^{* * *}$ & $0.1890^{* * *}$ & $0.0841^{*}$ & 0.0397 & 1.0000 & & \\
\hline VIE & $-0.0854^{*}$ & $-0.1318^{* * *}$ & $-0.1464 * * *$ & $0.0938 * *$ & 0.0728 & $0.1173^{* *}$ & $0.1442 * * *$ & 0.0180 & 0.0167 & 1.0000 & \\
\hline QSPE & -0.0620 & -0.0610 & 0.0717 & $0.1275^{* *}$ & -0.0135 & $0.0916^{* *}$ & $0.1463 * * *$ & 0.0071 & -0.0029 & $-0.3787^{* * *}$ & 1.0000 \\
\hline
\end{tabular}

* significant at 10\%; ** significant at 5\%, *** significant at $1 \%$

This table presents correlation analysis for key variables of interest where:

$M V E=$ Per share price at the end of the first quarter following the end of the fiscal year.

$B V A=$ Book value of assets scaled by total shares outstanding.

$B V L=$ Book value of liabilities scaled by total shares outstanding.

$M A X \_R I S K=$ Maximum VIE risk disclosed by the firm scaled by total shares outstanding.

I_RISK = idiosyncratic risk estimated as the standard deviation of residuals from estimating $E X R E T=\beta_{0}+$

$\beta_{1} R M R F+\varepsilon$ using monthly returns for five year windows, where EXERT = firm's monthly return - risk free rate (proxied as 3-month T-bill) and $R M R F=$ excess market return from Ken French's website.

$C F O=$ cash flow from operations

$S D \_C F O=$ standard deviation of cash flow from operations

$L E \bar{V}=$ debt-to-assets ratio

$B K \_M K T=$ book-to-market

$S I Z E=$ natural log of market value of equity

$P A Y E R=1$ if firm paid dividends

$R E T=$ buy-and-hold return for the fiscal year

$S O X=1$ if the firm presented an assessment of internal controls (in accordance with SOX).

$V I E=$ firm with maximum risk disclosures relating to a VIE following FIN 46

$Q S P E=$ firm disclosing involvement with qualified special purpose entities post SOX 
Table 3. Value Relevance of Maximum Risk Disclosures

MVE

\begin{tabular}{|c|c|c|c|}
\hline \multirow{2}{*}{$B V A$} & Model 1a & $\underline{\text { Model 1b }}$ & Model 1c \\
\hline & $\begin{array}{c}1.18 * * * \\
(6.75)\end{array}$ & $\begin{array}{c}1.18 * * * \\
(6.76)\end{array}$ & $\begin{array}{c}1.12 * * * \\
(5.83)\end{array}$ \\
\hline$B V L$ & $\begin{array}{c}-1.15 * * * \\
(-6.48)\end{array}$ & $\begin{array}{c}-1.15 * * * \\
(-6.44)\end{array}$ & $\begin{array}{c}-1.10 * * * \\
(-5.57)\end{array}$ \\
\hline MAX_RISK & $\begin{array}{c}-0.29 \\
(-1.61)\end{array}$ & & \\
\hline$M A X \_R I S K_{i t} * F I N A N C E_{i t}$ & & $\begin{array}{c}-0.29 \\
(-1.63)\end{array}$ & \\
\hline$M A X \_R I S K_{i t} * O P E R A T I N G_{i t}$ & & $\begin{array}{c}-2.17 \\
(-1.21)\end{array}$ & \\
\hline$M A X \_R_{L} S K_{i t} * O N-B O O K_{i t}$ & & & $\begin{array}{l}10.12 \\
(0.71)\end{array}$ \\
\hline$M A X_{-} R_{I S K_{i t}} * O F F-B O O K_{i t}$ & & & $\begin{array}{c}-0.27 \\
(-1.52)\end{array}$ \\
\hline Intercept & $\begin{array}{c}12.95 * * * \\
(4.80)\end{array}$ & $\begin{array}{c}13.35^{* * * *} \\
4.90\end{array}$ & $\begin{array}{c}13.00 * * * \\
4.80\end{array}$ \\
\hline $\mathrm{N}$ & 64 & 64 & 64 \\
\hline R-squared & 0.52 & 0.52 & 0.52 \\
\hline
\end{tabular}

This table presents OLS regression analysis of models $1 \mathrm{a}-1 \mathrm{c}$

$*$ significant at $10 \% ; * *$ significant at $5 \%, * * *$ significant at $1 \%$

Absolute value of robust t-statistics in parentheses

Where:

$M V E=$ Per share price at the end of the first quarter following the end of the fiscal year.

$B V A=$ Book value of assets scaled by total shares outstanding.

$B V L=$ Book value of liabilities scaled by total shares outstanding.

$M A X \_R I S K=$ Maximum VIE risk disclosed by the firm scaled by total shares outstanding.

$F I N A N C E=1$ if the VIE is structured to facilitate a financing or lease transaction.

$O P E R A T I N G=1$ if the VIE is structured to facilitate a joint venture, partnership, or investment.

$O N-B O O K=1$ if the maximum risk disclosure pertains to a consolidated VIE.

$O F F-B O O K=1$ if the maximum risk disclosure pertains to a VIE that is not consolidated. 
Table 4. Risk Impact of Disclosures Required by FIN 46 and SOX

\begin{tabular}{|c|c|c|c|c|c|c|}
\hline & & & \multirow[b]{2}{*}{$\frac{\text { Model } 2 f}{-0.075}$} \\
\hline $\mathrm{CFO}$ & $\begin{array}{r}\text { Model 2a } \\
-0.076 \\
(1.80)^{*}\end{array}$ & $\begin{array}{r}\text { Model 2b } \\
-0.066 \\
(1.59)\end{array}$ & $\begin{array}{r}\text { Model 2c } \\
-0.078 \\
(1.88)^{*}\end{array}$ & $\begin{array}{r}\text { Model 2d } \\
-0.074 \\
(1.76)^{*}\end{array}$ & $\begin{array}{r}\text { Model } 2 \mathrm{e} \\
-0.083 \\
(1.92)^{*}\end{array}$ & \\
\hline$S D \_C F O$ & $\begin{array}{c}0.276 \\
(4.32)^{* * *}\end{array}$ & $\begin{array}{c}0.257 \\
(4.15)^{* * * *}\end{array}$ & $\begin{array}{c}0.275 \\
(4.44)^{* * *}\end{array}$ & $\begin{array}{c}0.276 \\
(4.30)^{* * * *}\end{array}$ & $\begin{array}{c}0.280 \\
(4.37)^{* * * *}\end{array}$ & $\begin{array}{c}0.264 \\
(4.17)^{* * * *}\end{array}$ \\
\hline$L E V$ & $\begin{array}{c}-0.030 \\
(2.39) *\end{array}$ & $\begin{array}{c}-0.030 \\
(2.43)^{*}\end{array}$ & $\begin{array}{c}-0.032 \\
(2.52)^{* *}\end{array}$ & $\begin{array}{c}-0.031 \\
(2.43)^{* *}\end{array}$ & $\begin{array}{l}-0.028 \\
(2.21)^{*}\end{array}$ & $\begin{array}{c}-0.031 \\
(2.41)^{*}\end{array}$ \\
\hline$B K \_M K T$ & $\begin{array}{r}0.005 \\
(0.61)\end{array}$ & $\begin{array}{c}0.004 \\
(0.40)\end{array}$ & $\begin{array}{r}0.003 \\
(0.31)\end{array}$ & $\begin{array}{r}0.005 \\
(0.57)\end{array}$ & $\begin{array}{r}0.005 \\
(0.58)\end{array}$ & $\begin{array}{c}0.004 \\
(0.40)\end{array}$ \\
\hline$S I Z E$ & $\begin{array}{c}-0.004 \\
(2.46)^{*}\end{array}$ & $\begin{array}{c}-0.004 \\
(2.44)^{*}\end{array}$ & $\begin{array}{c}-0.003 \\
(2.11)^{*}\end{array}$ & $\begin{array}{c}-0.004 \\
(2.45)^{*}\end{array}$ & $\begin{array}{c}-0.003 \\
(2.11)^{* *}\end{array}$ & $\begin{array}{l}-0.003 \\
(1.99)^{*}\end{array}$ \\
\hline PAYER & $\begin{array}{c}-0.047 \\
(6.86)^{* * *}\end{array}$ & $\begin{array}{c}-0.046 \\
(6.84)^{* * *}\end{array}$ & $\begin{array}{c}-0.046 \\
(6.79)^{* * * *}\end{array}$ & $\begin{array}{c}-0.047 \\
(6.81)^{* * * *}\end{array}$ & $\begin{array}{c}-0.046 \\
(6.58) * * *\end{array}$ & $\begin{array}{c}-0.046 \\
(6.68)^{* * *}\end{array}$ \\
\hline RETURN & $\begin{array}{l}-0.010 \\
(1.14)\end{array}$ & $\begin{array}{l}-0.015 \\
(1.64)^{*}\end{array}$ & $\begin{array}{l}-0.010 \\
(1.16)\end{array}$ & $\begin{array}{l}-0.010 \\
(1.14)\end{array}$ & $\begin{array}{l}-0.011 \\
(1.23)\end{array}$ & $\begin{array}{l}-0.011 \\
(1.32)\end{array}$ \\
\hline$T R A N$ & & $\begin{array}{c}-0.024 \\
(5.18)^{* * * *}\end{array}$ & & & & \\
\hline POST & & $\begin{array}{c}-0.029 \\
(7.45)^{* * * *}\end{array}$ & & & & \\
\hline$S O X$ & & & $\begin{array}{c}-0.019 \\
(5.74)^{* * *}\end{array}$ & & & $\begin{array}{c}-0.025 \\
(5.51)^{* * *}\end{array}$ \\
\hline$V I E$ & & & & $\begin{array}{r}0.002 \\
(0.37)\end{array}$ & & \\
\hline$Q S P E$ & & & & $\begin{array}{r}0.002 \\
(0.21)\end{array}$ & & \\
\hline$T R A N^{*} V I E$ & & & & & $\begin{array}{l}-0.006 \\
(0.94)\end{array}$ & $\begin{array}{l}-0.012 \\
(1.70)^{*}\end{array}$ \\
\hline$T R A N^{*} Q S P E$ & & & & & $\begin{array}{l}-0.007 \\
(0.71)\end{array}$ & $\begin{array}{l}-0.012 \\
(1.26)\end{array}$ \\
\hline$P O S T^{*} V I E$ & & & & & $\begin{array}{c}-0.014 \\
(3.04)^{* * *}\end{array}$ & $\begin{array}{r}0.005 \\
(0.81)\end{array}$ \\
\hline$P O S T^{*} Q S P E$ & & & & & $\begin{array}{l}-0.012 \\
(2.26)^{*}\end{array}$ & $\begin{array}{r}0.006 \\
(0.96)\end{array}$ \\
\hline Constant & $\begin{array}{c}0.198 \\
(9.84)^{* * * *}\end{array}$ & $\begin{array}{c}0.216 \\
(10.67)^{* * * *}\end{array}$ & $\begin{array}{c}0.201 \\
(9.82)^{* * * *}\end{array}$ & $\begin{array}{c}0.199 \\
(9.80)^{* * *}\end{array}$ & $\begin{array}{c}0.197 \\
(9.63)^{* * *}\end{array}$ & $\begin{array}{c}0.203 \\
(9.66)^{* * * *}\end{array}$ \\
\hline Observations & 468 & 468 & 468 & 468 & 468 & 468 \\
\hline R-squared & 0.38 & 0.43 & 0.40 & 0.38 & 0.39 & 0.41 \\
\hline
\end{tabular}

This table presents OLS regression analysis of models $2 \mathrm{a}-2 \mathrm{f}$.

$*$ significant at $10 \% ; * *$ significant at $5 \%, * * *$ significant at $1 \%$

Absolute value of robust $t$-statistics in parentheses

Where:

$I_{-}$RISK $=$idiosyncratic risk estimated as the standard deviation of residuals from estimating EXRET $=\beta_{0^{+}}$

$\beta_{1} R M R F+\varepsilon$ using monthly returns for five year windows, where $E X E R T=$ firm's monthly return - risk free rate (proxied as 3-month T-bill) and $R M R F=$ excess market return from Ken French's website.

$C F O=$ cash flow from operations

$S D C F O=$ standard deviation of cash flow from operations

$L E \bar{V}=$ debt-to-assets ratio

$B K M K T=$ book-to-market

$S I Z E=$ natural log of market value of equity

$P A Y E R=1$ if firm paid dividends

$R E T=$ buy-and-hold return for the fiscal year

$T R A N=1$ if during the transition period $\left(20013^{\text {rd }}\right.$ quarter to $20024^{\text {th }}$ quarter $)$

$P O S T=1$ if during the post FIN 46 period $\left(20031^{\text {st }}\right.$ quarter to $20054^{\text {th }}$ quarter $)$

$S O X=1$ if the firm presented an assessment of internal controls (in accordance with SOX).

$V I E=$ firm with maximum risk disclosures relating to a VIE following FIN 46

$Q S P E=$ firm disclosing involvement with qualified special purpose entities post SOX

Note: observations are one per period (PRE, TRAN, POST) per firm. 